\title{
Has the Association of Research Libraries Proved Worth While?
}

$I^{1}$ T Is very fitting that a number of College and Research Libraries which is published in honor of Charles Harvey Brown should have some discussion of the value of the Association of Research Libraries, as he was one of the founders and has guided its progress during its fifteen years of life. At New Haven in 1931 the American Library Association meetings were so well attended that even the section meetings were too large for easy discussion. The librarians of some of the great research libraries felt they had problems which were not shared by the staffs of smaller institutions. If they could get together in a small group and discuss their mutual problems, they were sure that the meetings would be profitable.

Charles H. Brown, James T. Gerould, and Phineas L. Windsor constituted themselves as a committee to establish such an organization. They called a meeting at the Drake Hotel in Chicago on Dec. 29, 1932, during the midwinter session of the American Library Association. They invited the heads of libraries represented in the Association of American Universities, as well as the librarians of a few other libraries which were recognized as great research institutions. Forty-three libraries were represented at this first meeting.

The organization of the association was and still is extremely simple. The principal officer is the executive secretary, elected for a five-year term. Donald B. Gilchrist was the first executive secretary. He was followed by Keyes D. Metcalf and then by
Paul North Rice. Charles W. David, of the University of Pennsylvania, has just started the fourth five-year term. The only other officers are an advisory committee of five elected for five-year terms.

Mr. Brown served as nominating committee chairman at the first meeting, and accordingly he alone of the three founders was not on the original advisory committee. Since then he has twice served a term on that committee. Indeed, he is the only man who has served more than one term during the fifteen years since the association was formed.

The original conception of the association has been carried out. With one or two exceptions there have been no prepared papers. The executive secretary makes up an agenda of topics suggested by the membership. The senior member of the advisory committee present presides, and the discussion is informal. No stenotypist is present to discourage the freest expression of opinion. The skeleton minutes made up by the executive secretary are confidential and distributed only to members.

From the discussion at these meetings have come certain results that were significant to many libraries not members. Doctoral Dissertations Accepted by American Universities has been published annually since 1934. This list was first edited by Donald B. Gilchrist, then by Edward A. Henry, and in more recent years by Arnold H. Trotier. It is printed by the H. W. Wilson Company but financed by the asso- 
ciation, which may account for its never having been sold on a service basis.

A still more ambitious publication which was sponsored by the Association of Research Libraries is the Catdlog of Books Represented by Library of Congress Printed Cards. At early meetings of the association there was much discussion of the importance of duplicating the Library of Congress catalog. After considering a film duplication, it was decided that a printed catalog would be far preferable. A committee consisting of Harvie Branscomb, Keyes D. Metcalf, and James T. Gerould tried in vain to secure permission from the Librarian of Congress for such a catalog. Because of his unfortunate opposition it was abandoned. It is interesting to note that his two main objections were the fear that the orders for Library of Congress cards would decrease if it was possible to copy entries from a printed catalog and the desire to correct mistakes before the cards were reprinted. While the Association of Research Libraries committee was sure that a printed cata$\log$ bearing Library of Congress card numbers would increase the sale of cards and was equally sure that the need for correcting mistakes would never decrease, there was nothing to do but postpone the plan.

In 1940 a new committee was appointed to reopen the matter with Archibald MacLeish, the new Librarian of Congress. This committee was eventually successful not only in persuading the Library of Congress that the catalog should be printed but in securing Edwards Brothers to do the publishing and in persuading the Rockefeller Foundation to subsidize the project by purchasing fifty sets for foreign libraries at a cost of $\$ 3750$. There is little chance that the catalog would have been published if it had not been for the efforts of the Association of Research Libraries. Encouraged by this success the association has sponsored a photo-offset copy of the British Museum Catalogue and a supplement to the Catalog of Books Represented by Library of Congress Printed Cards covering the four-anda-half years up to Dec. 3I, 1946.

\section{Discussions}

Discussions at Association of Research Libraries meetings have not usually produced such tangible results as publication. Indeed some times the results are merely much talk. That might be said to be the result of the constant discussion of the H. W. Wilson Company's service basis. Careful investigations and reports on the service basis have been made by Miles $O$. Price and M. Llewellyn Raney, and the matter has been much discussed. Had the Association of Research Libraries been able to influence the Wilson Company, the service basis would have been abandoned for at least some of the publications where it seemed most illogical.

But if the discussion of this controversial topic has to date brought little result, much has come from other subjects under discússion. The anxiety of the great libraries to get European books unavailable because of the difficulty in purchasing was constantly discussed with representatives of the Library of Congress, which under Mr. MacLeish and Luther H. Evans has been actively cooperating in Association of Research Libraries meetings. A direct result of these discussions was the magnificent offer of the Library of Congress to purchase cooperatively European books published during World War II, and with full agreement of the association, this opportunity was shared with many libraries not members of the Association of Research Libraries.

It cannot be emphasized too much that when results come from the Association of Research Libraries discussions they will surely be shared by all interested. There 
must be a small group if there is to be real discussion. If out of that discussion there should come a report of a committee on statistics of libraries, such as the report recently made by Robert Bingham Downs, the whole library world will have the benefit of the report.

\section{Membership of A.R.L.}

Just before his retirement as librarian of Iowa State College Mr. Brown headed a movement which will go far to assure that the Association of Research Libraries continues to function with maximum usefulness. The membership had gradually grown to forty-seven institutions. Many libraries not members were anxious to belong. It was clear that some of the nonmember institutions had more reason for belonging than some of the older members.

The advisory committee was instructed to consider this whole matter of increase or change in membership, and Charles $\mathrm{H}$. Brown, then a member of the advisory committee, was made chairman of a committee to make definite recommendations. It was felt that election for life was not the best thing for the association. It was feared that if the organization continued to increase it would soon be too large for informal discussion. At the suggestion of $\mathrm{Mr}$. Brown, the association agreed to have the membership limited to forty-five members. Ten new members were nominated, and the forty-seven existing members then voted for forty-five of the fifty-seven existing and suggested members. After much investigation, Mr. Brown was able to furnish tables showing the size, growth, and book expenditure of the various libraries. The final vote retained forty-three of the forty-seven old members and added two of the newly nominated.

With this strengthening in membership, the Association of Research Libraries is starting its sixteenth year. The Farmington plan for the division of responsibility of full coverage in the purchase of foreign books is the subject which is receiving most attention at the moment by members of the association.

It is hoped that this short résumé may be convincing proof that the Association of Research Libraries has been proved worth while. The informal discussion by a small group of librarians facing similar problems has been most helpful. When the discussion has developed into a definite proposal or publication, much of the library world has profited. It is fair to say that in its original conception, in its fifteen years of progress, and in its present reorganization the association owes much to Charles Harvey Brown. 